\title{
RUANG RAJUTAN KEBERAGAMAN MASYARAKAT PASAR BARU
}

\author{
Veren Calisca ${ }^{1)}$, Fermanto Lianto ${ }^{2)}$ \\ 1) Program Studi S1 Arsitektur, Fakultas Teknik, Universitas Tarumanagara, veren896@gmail.com \\ 2) Program Studi S1 Arsitektur, Fakultas Teknik, Universitas Tarumanagara, fermantol@ft.untar.ac.id

\begin{abstract}
Abstrak
Ruang sosial tidak hanya sekedar terbentuk oleh aspek fisik belaka, namun juga memiliki aspek-aspek non-fisik yang terbentuk oleh aspek-aspek budaya dan keseharian masyarakatnya. Aspek non fisik tersebut dikenal sebagai Genius Loci atau Sense of Place yang bersifat unik di setiap kawasan yang berbeda. Identitas dari Sense of Place tersebut mengandung prinsip-prinsip pada pembentukan place sebagai tempat berkumpul masyarakat kreatif dimana mereka tak hanya bersosialisasi namun juga saling bertukar ide sebagai sumber daya ekonomi kreatif yang menjadi landasan perkembangan dari suatu kota. Namun, ruang-ruang yang terbentuk hanya menyisakan ruang sisa sebagai tempat berkumpul di antara padatnya bangunan. Ruang ketiga yang hadirpun terletak jauh dari jangkauan masyarakat lokal. Kawasan Pasar Baru merupakan salah satu lokasi di Jakarta dengan diversitas yang tinggi sebagai salah satu syarat terbentuknya creative place. Sebagai salah satu pusat ekonomi Jakarta, Pasar Baru kini telah kalah populer dengan pusat perbelanjaan modern. Kurangnya wadah bagi kegiatan kreatif masyarakat juga menghambat perkembangan ekonomi yang kini berfokus pada kreatitas. Melalui metode observasi terhadap sekuen aktifitas pelaku kegiatan di kawasan Pasar Baru serta literatur ruang sosial sebagai third place, maka ditransformasikan desain yang mencirikan keberagaman melalui Ruang Rajutan Keberagaman Masyarakat Pasar Baru sebagai sentra ekonomi yang berbasis kreatifitas masyarakat selaku third place bagi kawasan Pasar Baru.
\end{abstract}

\section{Kata kunci: diversitas; ekonomi kreatif; genius loci; Pasar Baru; third place}

\begin{abstract}
Social space as a whole is defined not only through its physical aspect, but also the intangible culture and tradition of its people. The non-physical aspect is commonly known as Genius Loci or sense of place which is distinctive and unique in each different places. The identity of Genius Loci covers the groundwork principle of creating place as a meeting point for the creative class where they could interact with each other to generate ideas collectively as the foundation of creative economy, generating the development of an urban area. Space is surrounded by high density building in Pasar Baru area, which left the remaining negative space as third place. Pasar Baru is one of the districts in Jakarta with such diversed cultural identity which is one of the main principle in creating the creative place. Unfortunately, the district's popularity as one of the main shopping area in Jakarta had faded due to the significant growth of shopping malls as new economic centres of the city. Design is created based on observation method through activity sequence of Pasar Baru citizen and literature research of social space as third place. Through the presence of cultural diversity such as festivals, staple culinary, ethnicity, creative products, to architectural style, it is hoped to aid in revitalizing Pasar Baru not only as a shopping distric but as a creative economy hub as well through Socail Linkage of Pasar Baru Diversity as a third place.
\end{abstract}

Keywords: creative economy; diversity; genius loci; Pasar Baru; third place

\section{PENDAHULUAN}

Paradigma pusat perkembangan ekonomi terus mengalami perubahan. Pada masa agrikultural, ekonomi bersifat lokal dimana persaingan ekonomi lemah namun pada masa industrial di abad ke-18 persaingan ekonomi bersifat global, persaingan yang awalnya lemah 
menjadi sangat kuat. Pusat perkembangan ekonomi modern dipusatkan pada efisiensi, spesialiasi, dan pembentukan divisi kerja (Smith, 1776). Memasuki abad ke-21, terjadi perubahan dimana penggerak ekonomi berfokus pada kreatifitas.

Perkembangan ekonomi masa kini berpusat pada inovasi. Diversitas pada kota nyatanya terdapat pada masyarakat dengan berbagai latar belakang baik tastes, skill, needs, dan supplies. Buruh, modal, dan teknologi yang baik tidak akan berguna apabila masyarakatnya tidak dapat berkolaborasi. Kolaborasi dalam masyarakat dapat dijalin bila kualitas kotanya kreatif. Lingkungan kreatif mempunyai diversitas yang memberikan banyak pilihan kebebasan masyarakat untuk memilih (Jacobs, 1961).

Lingkungan kota terdiri atas tiga jenis ruang yaitu first place (home), second place (work) yang diperantarai third place (Winata, 2019). Manusia selalu bergerak dari tempat tinggal ke lingkup kerja. Di waktu senggang mereka berkumpul ke ruang perantara. Pada ruang antara ini terbentuklah komunitas dan menciptakan sebuah budaya. Peran Third place tidak hanya sekedar menyediakan ruang namun bagaimana dia dapat menciptakan komunitas budaya yang kreatif.

Creative Class merupakan komunitas dimana ide sebagai pembentuk ekonomi global yang baru. Human capital (gagasan dan ide hasil pemikiran manusia) menjadi unit pendorong ekonomi dan masyararakat yang kreatif. Kunci terbentuknya komunitas kreatif terletak pada prinsip 3T, yakni Technology, Talent, dan Tolerance (Florida, 2002).

Kemajuan teknologi meningkatkan kapitalisme dalam menciptakan lingkungan yang efisien dan produktif. Dibalik itu terdapat human capital sebagai kunci utama perkembangan ekonomi didukung oleh toleransi (terbuka pada diversitas) yang menstabilkan teknologi dan talenta sebagai kunci pendorong ekonomi. Dengan adanya toleransi menarik orang-orang kreatif untuk berkumpul dan meningkatkan talenta dan teknologi sebagai kunci ekonomi.

Prinsip 3T tersebut memerlukan sebuah ruang yang mewadahinya yang dikenal sebagi T keempat, Territorial Asset. Kualitas ruang yang tercipta harus memiliki karakteristik yang menjadikan ruang tersebut diverse. Diverse dari segi lingkungan yang terbentuk, orang, dan aktifitas yang tersedia agar dapat menjadi ruang yang berkarakter dan atraktif. Ruang yang berhasil tidak hanya menyediakan satu hal namun variasi dalam kualitas ruang bagi orang yang berbeda-beda.

Diversitas ruang hadir di ruang kota seperti di Pasar Baru, Jakarta. Pasar Baru merupakan sentra ekonomi yang memiliki banyak variasi dari segi etnis masyarakat, budaya, heritage, dan aktifitas yang berkembang di Pasar Baru seperti seniman jalanan, makanan, dan tekstil. Namun Pasar Baru kini tertimbun oleh perkembangan pasar modern seperti shopping mall dan online shop menjadikannya sepi pengunjung. Diversitas yang ada tidak terawat dan menjadikannya tidak terdengar oleh publik. Melalui pemanfaatan dan desain yang baik diharapkan dapat meningkatkan perekonomian Pasar Baru sebagai ruang komunitas kreatif.

\section{KAJIAN LITERATUR}

Perencanaan ruang kota cenderung mensimplikasi permasalahan keruangan. Terdapat dua penggunaan space, yaitu sebagai geometri tiga dimensi atau sebagai hasil dari persepsi. Keruangan kota sering disederhanakan dengan membagi space menjadi space yang lebih kecil. Ruang kota yang diproduksi bersifat institusional dan jauh dari praktek keruangan sehari-hari. Konsep ruang kota lebih dari bentukan fisik. Levebre menjelaskan peran masyarakat dalam pembentukan ruang abstrak menjadi tiga jenis konsep yang saling terhubung, yaitu physical space, mental space, dan social space atau disebut juga sebagai perceived, conceived, dan lived (Levebre, 1992).

Physical space merupakan bentuk keruangan hasil persepsi (dipengaruhi budaya). Mental space merupakan bentuk dari ruang yang telah direncanakan dalam skala urban seperti, master plan, zoning plan. Social space merupakan hasil dari praktek keruangan sehari-hari dan bentukannya secara fisik dapat berubah-ubah dibandingkan physical space dan mental space yang cenderung mempertahankan bentukan fisiknya. 
Levebre mengungkapkan bahwa ruang kota lebih dari lokasi yang direncanakan secara fisik; ruang merupakan bentuk dari praktek keruangan secara sosial membentuk place. Place dapat ditinjau melalui space dan character yang membentuknya menjadi lived space. Character merupakan komponen utama dalam pembentukan place (Schulz, 1979).

Character menunjukkan atmosfir yang bersifat abstrak secara keseluruhan, namun disisi lain juga memiliki bentukan fisik seperti elemen pembentuk ruang. Segala bentukan fisik juga dapat menggambarkan character. Pada tiap aktifitas yang berbeda memerlukan character yang berbeda seperti pada rumah tinggal yang bersifat "aman", kantor bersifat "praktikal", dan gereja bersifat "formal". Dengan demikian menjadikan character bagian penting dalam pengalaman ruang.

Manusia selalu bergerak pada tiga jenis ruang, yaitu tempat ia tinggal (first place) ke tempat ia bekerja (second place) yang diperantarai ruang publik (third place). Ruang publik diartikan sebagai suatu tempat yang dapat digunakan oleh siapapun tanpa pembatasan ekonomi atau sosial. Third place diperlukan bagi semua orang karena merupakan tempat dimana orang dapat melepaskan kepenatan yang terjadi pada aktivitas keseharian mereka.

Oldenburg mencatat bahwa third place memiliki setidaknya tujuh karakter ruang yang unik. Karakter third place merupakan tempat yang netral, dimana setiap orang yang pergi ke third place, memiliki kedudukan yang sama, tidak ada hirarki maupun status. Pengunjung yang datang meninggalkan semua atribut keseharian mereka seperti jabatan, fungsi management, latar belakang budaya bahkan status marital. Kondisi ini menyebabkan hilangnya tingkat perbedaan antar manusia yang menjadi karakter third place yang kedua.

Pengunjung third place adalah pengunjung regular, hal ini terjadi karena third place merupakan bagian dari komunitas suatu desa atau area (district). Kedekatan antar pengunjung merupakan hal terpenting dalam pembentukkan third place, sehingga hal ini kemudian tercermin dalam pembentukkan third place. Third place merupakan bagian dari komunitas, karena itu aksebilitas menjadi hal penting. Masyarakat perlu suatu tempat berkumpul yang "netral", tanpa pritensi dan tentunya mudah diakses baik secara fisik maupun finansial.

Third place sebagai tempat dimana masyarakat berkumpul, dan memiliki status yang sama sehingga third place menjadi tempat netral, dan sederhana (unpretentious). Kesederhanaan ini penting agar masyarakat dapat datang tanpa keraguan. Arsitektur dalam pembentukannya terkadang menggunakan simbol-simbol tertentu, sehingga menimbulkan interpretasi bagi masyarakat tertentu. Interpretasi inilah menyebabkan timbulnya segregasi dan keenganan untuk datang ke bangunan tertentu. Kesederhanaan ini membuat third place menjadi tempat yang terbuka bagi siapa saja.

Third place sebagai tempat pertemuan didominasi dengan aktivitas perbincangan. Karakter terakhir yang terpenting dari third place, tempat ini haruslah playful atau menyenangkan bagi siapapun, sehingga ketika meninggalkan third place, orang keluar dengan muka tersenyum dan kembali ke rumah dengan perasaan gembira. Third place tidak hanya menjadi tempat untuk suatu masyarakat berkumpul melainkan tempat dimana masyarakat dapat menemukan kegembiraan dalam kebersamaan (Oldenburg, 1999).

Pembentukan ruang sosial pada masyarakat kota memerlukan pendekatan dan pemaknaan yang berbeda. Mekanisme dalam pembentukan ruang sosial berbeda dengan komunitas masyarakat desa (tradisi). Kesulitannya terjadi dikarenakan masyarakat kota bukan monokultur atau homogen. Komposisi ini terbentuk diakibatkan banyaknya pendatang yang membawa berbagai macam latar belakang budaya. Pencampuran ini menimbulkan bentukan budaya baru yang semakin dipermudah dengan adanya internet dan kecanggihan teknologi.

Creativity Age merupakan jaman dimana creativity menjadi unit wajib bagi perkembangan teknologi, industri, dan perekonomian. Creativity telah menjadi etika dalam sistem kehidupan masyarakat (Florida, 2002). Terdapat tiga point utama mengenai creativity, yaitu pertama creativity telah menjadi hal utama dalam cara hidup dan kerja masyarakat. Kedua, creativity tidak terbatas pada inovasi teknologi dan model bisnis, creativity memerlukan kebiasaan berpikir yang berbeda dan tidak hanya terbatas pada individual saja namun juga dalam 
masyarakat. Etika creative menjadikannya karakter dan identitas masyarakat. Ketiga, proses creative tidak terjadi pada individual namun memerlukan sekelompok orang membentuk Creative Class.

Creative Class merupakan orang-orang dengan berbagai diversitas latar belakang pendidikan yang terlibat dalam proses bekerja secara creative. Inovasi menjadi unit utama pertumbuhan kota, ditunjang oleh kualitas place yang menumbuhkan etika creative masyarakat (Jacobs, 1961). Place merupakan unit utama yang mengatur perekomonian dan masyarakat menggantikan peran yang dulu dipegang perusahaan besar. Terdapat empat prinsip pembentukan place sebagai panduan dan strategi untuk menghadirkan pertumbuhan dan perkembangan, yaitu diversity, choice, authenticity, dan connections.

Diversity mencangkup baik lingkungan budaya dan alam sekitar, perpaduan antar keduanya menghasilkan kontras yang menarik; hal tersebut juga berlaku pada bangunan tua dan baru, dari perbedaan fungsi dan program, maupun perbedaan budaya dan masyarakat yang ada. Choice merupakan hasil dari diversity, memberikan kebebasan memilih dalam berbagai aspek kehidupan seperti pilihan moda transportasi, lingkungan kerja, sarana hiburan, dan lainnya.

Authenticity merupakan preservasi fitur-fitur asli kawasan yang mencangkup bangunan historis, tradisi lokal, budaya masyarakat hingga bisnis-bisnis lokal. Kumpulan dari fitur-fitur tersebut menciptakan karakteristik yang unik sebagai refleksi dari kekayaan citra budaya lokal. Connections merupakan jalinan baik antar manusia dengan ide, alam, sejarah, budaya, dan inspirasi sebagai nyawa dari kreatifitas. Places yang didesain untuk memaksimalkan jalinan antara manusia dan lingkungan akan memaksimalkan peluang kreatif yang muncul.

\section{METODE}

Penelitian menjabarkan empat indikator pembentukan ruang kreatif di Pasar Baru melalui empat tahapan penelitian yang menggunakan metode berupa literatur, observasi, wawancara, dan studi kasus sebagai dasar atas pemilihan dan penyusunan program bagi proyek Ruang Rajutan Keberagaman Masyarakat Pasar Baru sebagai tahap perencanaan awal (lihat gambar 1).

Langkah pertama melalui studi literatur yang berfokus pada teori yang dikemukakan dua orang tokoh yaitu Norberg Schulz dan Richard Florida. Spirit of Place merupakan unsur penting dalam desain sebagai pembentuk character dalam ruang (Schulz, 1979) serta pembentukan ruang sebagai wadah aktifitas masyarakat kreatif menjadi penggerak ekonomi masa kini (Florida, 2002).

Langkah kedua adalah observasi dengan melakukan mapping kawasan. Melalui observasi diperoleh titik-titik first place, second place, third place yang berpusat di Jl. Antara, J. Pintu Air, dan JI. Pasar Baru. Ditemukan juga fitur kawasan berupa langgam arsitektur, bangunan historis, kebudayaan dasar pembentukan ruang kreatif (Florida, 2002).

Langkah ketiga melalui wawancara dengan pelukis jalanan, konsumen yang berbelanja, karyawan di pertokoan Pasar Baru, tukang parkir, tukang bajaj, dan pedagang kaki lima. Melalui wawancara ditemukan kebutuhan user Pasar Baru serta sequence of activity di Pasar Baru.

Langkah keempat melalui studi kasus terhadap lima objek yang serupa dengan rencana proyek dengan membandingkan kriteria berupa tipologi, kekurangan dan kelebihan objek studi kasus, zoning, luasan program, bentuk sirkulasi, susunan massing, dan kaitan objek studi kasus terhadap konteks kawasannya.

Temuan yang diperoleh melalui empat tahapan proses penelitian tersebut digunakan sebagai materi sintesa program, zoning, serta massa bangunan pada tahap awal perencanaan proyek Ruang Rajutan Keberagaman Masyarakat Pasar Baru. 


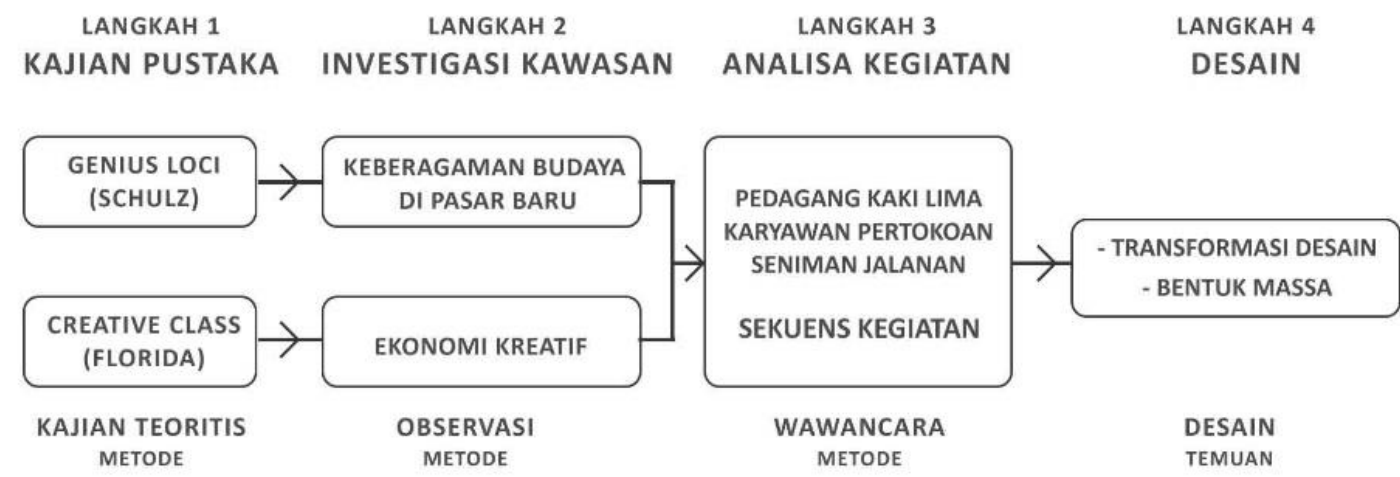

Gambar 1. Skema tahapan metode penelitian Sumber: Penulis, 2020

Terdapat metode yang digunakan peneliti dalam mengumpulkan data, diantaranya: survei lapangan, wawancara, dan studi literatur. Survei dilakukan langsung dengan melakukan pengamatan di Kelurahan Pasar Baru untuk menentukan site. Setelah melakukan survei, penulis melakukan wawancara yang bertujuan memperoleh data terkait user di Kelurahan Pasar Baru. Untuk melengkapi data-data terkait kawasan, penulis melakukan studi terhadap literatur yang membahas mengenai Kelurahan Pasar Baru.

Terdapat dua jenis data yang dikumpulkan pada penelitian, yakni:

a. Data Primer

Merupakan data-data yang diperoleh secara langsung melalui survei lapangan dan hasil wawancara dengan pihak terkait. Data Primer meliputi kondisi fisik Kelurahan Pasar Baru, kondisi non fisik Kelurahan Pasar Baru, fasilitas sosial, data kependudukan dan peraturan pemerintah.

b. Data Sekunder

Merupakan data yang diperoleh dari studi literatur yang berhubungan dengan konsep Ruang Rajutan Keberagaman Masyarakat Pasar Baru.

\section{DISKUSI DAN HASIL}

Keberagaman masyarakat di kawasan Pasar Baru dapat ditelusuri dari sisi sejarah perkembangan kawasan Pasar Baru. Pada tahun 1600, peternak dan pedagang chinese didatangkan ke Indonesia oleh pemerintah Belanda untuk membantu mengembangkan perekonomian. Area di sekitar kali Ciliwung lalu dikembangkan sebagai kawasan pemukiman chinese yang dikenal dengan nama Weltevreden. Area ini lalu berkembang sebagai pusat perekonomian dan pemerintahan pada tahun 1733. Pasar Baru kemudian dibangun oleh Daendels tahun 1820 sebagai pusat perekonomian baru bagi kalangan masyarakat menengah ke atas. Pedagang India mulai masuk ke kawasan Pasar Baru untuk berjualan tekstil pada tahun 1859 dan terjadilah akulturasi budaya antara pedagang chinese dengan pembeli asal Belanda, Jepang, pedagang India dan masyarakat lokal. Selain berperan sebagai pusat ekonomi, pada kawasan Pasar Baru juga pernah dilaksanakan beberapa kegiatan penting dalam sejarah kemerdekaan Indonesia seperti diadakannya Kongres Pemuda, didirikannya LKBN, diresmikannya Komite Nasional Indonesia Pusat oleh Ir. Soekarno serta didirikannya tugu pembebasan Irian Barat yang kini dikenal dengan nama Lapangan Banteng.

Pasar Baru memiliki banyak jenis diversitas mulai dari aspek fungsi, langgam arsitektur, etnis, kuliner, dan festival budaya yang berkembang. Keberagaman seperti yang dikemukakan oleh Florida merupakan salah satu indikator terpenting dalam pembentukan ruang kota yang kreatif, dikombinasikan dengan kondisi eksisting Pasar Baru sebagai pusat perekonomian maka muncul potensi dalam mengembangkan kawasan tersebut sebagai sentra ekonomi kreatif. 
Pasar Baru memiliki diversifikasi fungsi seperti fungsi komersial berupa pertokoan yang terletak di sepanjang Jl. Pasar Baru, fungsi hunian yang terletak di belakang kawasan pertokoan tersebut, fungsi pemerintahan dan fasilitas sosial budaya yang terletak di sebelah selatan Jl. Pos, fungsi ruang terbuka hijau yaitu pada Lapangan Banteng, dan ruang terbuka biru yaitu Kali Ciliwung (lihat gambar 2).
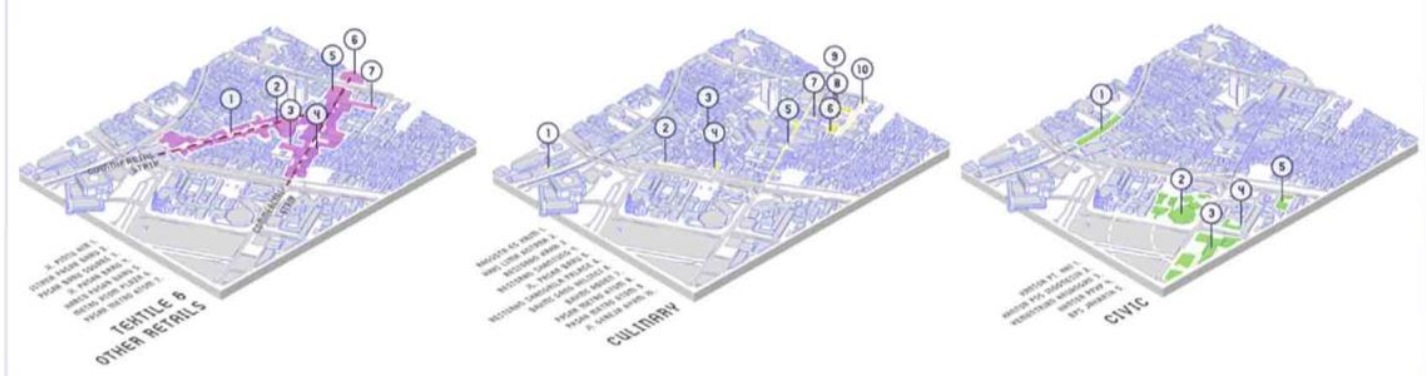

Gambar 2. Diagram Analisis Site Sumber: Penulis, 2020

Tak hanya sekedar melalui fungsi, Pasar Baru juga mempunyai diversifikasi melalui langgam bangunan mulai dari jajaran bangunan historis berlanggam neoklasik di sepanjang Jl. Pos seperti Gedung Kesenian Jakarta, Gedung Fillateli, Sekolah Santa Ursula. Bangunan dengan langgam Gothic dapat ditemukan pada bangunan Katedral Jakarta dan langgam modern pada bangunan Masjid Istiqal. Di sepanjang Pasar Baru terdapat jajaran fasad pertokoan dengan campuran langgam seperti modern, kolonial, hingga tradisional chinese (lihat gambar 3).

Keberagaman etnis di Pasar Baru sudah ada sejak pembentukan kawasan kecuali orang eropa atau belanda yang telah meninggalkan kawasan ini sejak kemerdekaan tahun 1945. Komunitas chinese merupakan etnis dominan diikuti komunitas india dan pakistan. Diversitas di Pasar Baru juga terlihat pada bangunan religi yang dibentuk oleh komunitas di sana. Terdapat dua kelenteng (Kelenteng Sin Tek Bio dan Kelenteng Kuan Im Bio), dua masjid, dua gereja (Gereja PNIEL dan Gereja GKI), dan Kuil Sikh. Sejak tahun 2000 terdapat pusat peribadahan seperti Sai Baba, Graha Sindu, dan Hare Krishna (lihat gambar 4).

Keberagaman latar belakang etnis dan budaya di Pasar Baru memungkinkan terjadinya interaksi antar etnis dan budaya yang sudah lama berkembang di Pasar Baru. Terlihat jelas bahwa dengan adanya eksistensi bangunan keagaman yang berdiri berdekatan menunjukkan adanya toleransi antar komunitas di Pasar Baru.

Kebebasan memilih di Pasar Baru dapat dikaitkan melalui aksesbilitas yang memungkinkan kehadiran berbagai kalangan kreatif pada third place di kawasan tersebut seperti yang terlihat pada jenis moda transportasi publik yang tersedia, diversifikasi skala jalan, serta objek yang dapat ditemui dan dikunjungi dalam radius walkable distance pejalan kaki.

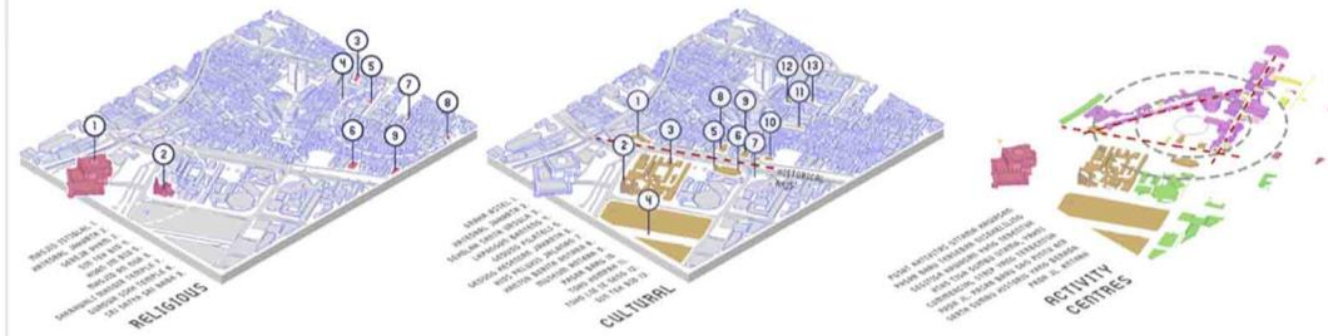

Gambar 3. Diagram Analisis Site Sumber: Penulis, 2020

Terdapat beberapa moda transportasi publik yang tersedia di Pasar Baru seperti kereta api, busway, dan bus pariwisata. Kereta api yang dapat diakses melalui Stasiun Juanda terhubung dengan rute ke arah utara melalui Stasiun Sawah Besar yang berakhir di Stasiun Kota dan Stasiun 
Gambir yang merupakan salah satu stasiun antar kota yang melayani perjalanan ke luar daerah dari kota Jakarta. Terdapat dua halte Bus Transjakarta yang terdapat di kawasan Pasar Baru yaitu halte Pasar Baru dan halte Juanda. Di Pasar Baru juga terdapat bus pariwisata yang dapat diakses melalui halte bus Juanda yang terhubung dengan rute Kota Tua - Plaza Indonesia.

Terdapat beberapa jenis jalan di Pasar Baru seperti, jalan arteri, jalan kolektor, dan jalan lokal. Jalan arteri yang terletak di sebelah utara yaitu di Jl. Samanhudi, di sebelah timur yaitu di Jl. Gunung Sahari. Jalan kolektor di sebelah selatan yaitu di Jl. Pos yang menghubungkan kawasan Juanda dan Gunung Sahari, dan di sebelah timur yaitu di Jl. Juanda 1 serta JI. Pasar Baru yang menghubungkan Jl. Samanhudi dengan JI. Juanda Raya.
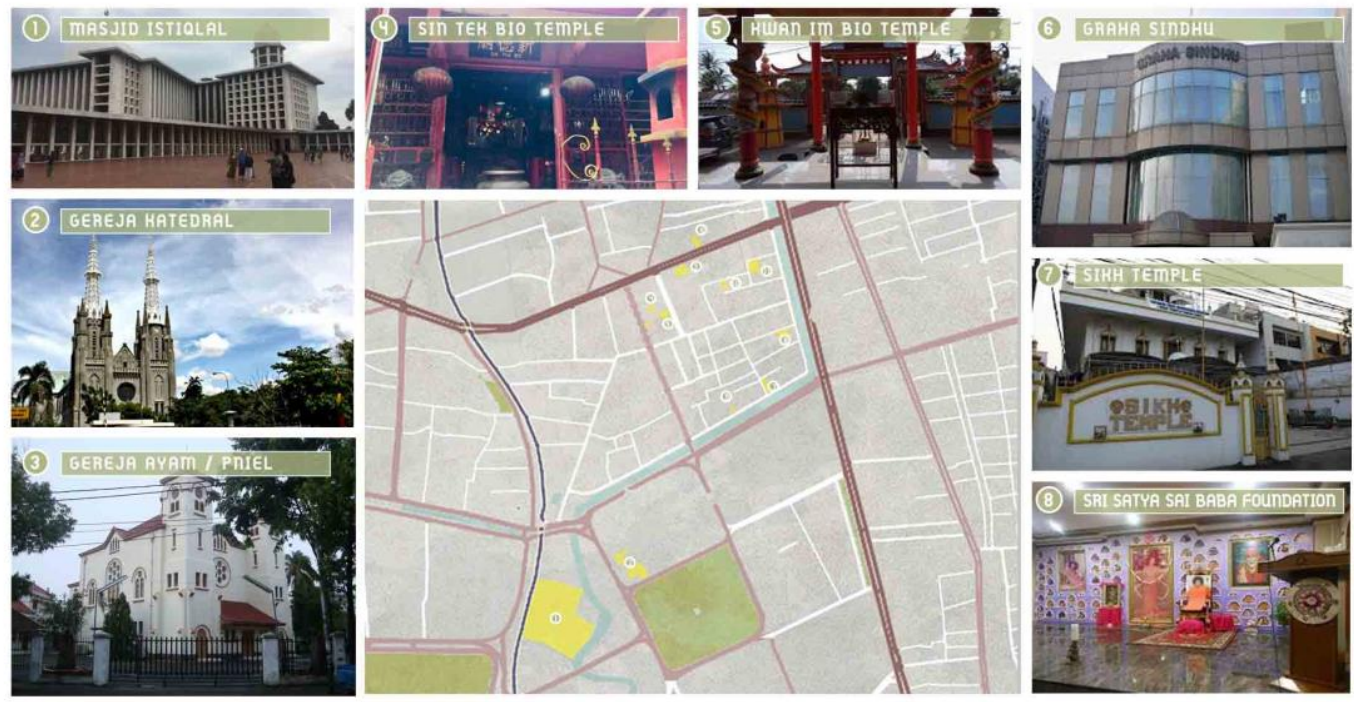

DIVERSITAS BATGUNAT RELIGIUS DI KELURAHAT PASAR BARU

Gambar 4. Keragaman tempat ibadah pada kawasan Pasar Baru (kuning)

Sumber: google.com, diunduh pada 6 Januari 2020

Secara makro Kelurahan Pasar Baru terbagi menjadi dua bagian yakni bagian utara dan selatan yang terbagi oleh Jl. Pos dan Kali Ciliwung. Pada bagian utara memiliki karakteristik ramah terhadap pejalan kaki dikarenakan beberapa faktor, diantaranya kanopi di sepanjang jalur pejalan kaki sebagai peneduh, skala jalan yang ramah bagi manusia, dan kehadiran pertokoan dan PKL yang menghidupi susasana jalan khususnya di Jl. Pasar Baru. Kemudian di sisi selatan dengan karakteristik jalan yang didominasi oleh kendaraan mengakibatkan jalur pedestrian yang terdapat di sisi jalan tidak nyaman dikarenakan saling memotongnya akses antara pejalan kaki dan kendaraan.

Authenticity berkaitan dengan sense of place atau genius loci yang mencakup bentuk fisik dan non-fisik maupun sosial budaya yang ada di kawasan tersebut. Kehadiran sense of place di Pasar Baru dapat ditinjau melalui beberapa fitur budaya seperti bangunan-bangunan cagar budaya, festival kebudayaan, kuliner lokal, dan kehadiran toko atau bisnis yang dimiliki warga lokal secara turun menurun.

Fitur kawasan membentuk citra fisik melalui kehadiran bangunan cagar budaya di Pasar Baru. Bangunan cagar budaya tersebut tersebar secara dominan di Jl. Pasar Baru, Jl. Antara, dan Jl. Pos. Pada Jl. Pasar Baru dapat ditemukan bangunan Kelenteng Sin Tek Bio yang dibangun pada abad ke-17 sebagai pusat peribadatan warga keturunan Tiong Hoa. Bangunan ibadah lainnya adalah Gereja PNIEL atau dikenal sebagai Gereja Ayam yang dibangun pada era kolonial pada sebelah utara Pasar Baru. Selain sepanjang Pasar Baru sendiri juga terdapat berbagai toko yang dibangun pada era yang berbeda dengan yang tertua seperti Toko Kompak atau Toko Lie le Seng yang memiliki langgam tradisional chinese dan berusia setua Pasar Baru sendiri.Pada Jl. Antara dapat ditemukan bangunan-bangunan dengan langgam kolonial seperti Gedung Antara yang merupakan pusat kantor berita Antara pada awal kemerdekaan Indonesia. Di seberang Jl. Antara 
terdapat pula jajaran bangunan kolonial disepanjang Jl. Pos seperti Gedung Kesenian Jakarta, Gedung Filateli, dan Gedung Santar Ursula dengan langgam Neo Klasik. Selain langgam tersebut juga terdapat langgam Neo Gothic yang terdapat pada Gereja Katedral. Secara kontras terdapat pula bangunan dengan langgam modern yang dibangun setelah kemerdekaan Indonesia seperti Masjid Istiqal dan Lapangan Banteng yang menjadi ikon budaya tidak saja bagi Pasar Baru tapi juga kota Jakarta (lihat gambar 4).

Festival merupakan suatu cara komunitas mengekspresikan identitasnya, merayakan shared value dan memperkuat ikatan dalam komunitas. Sepanjang sejarah terdapat beranekaragam festival yang berkembang di Pasar Baru terkait dengan diversifikasi kelompok etnis yang tinggal disana. Perayaan Sinterklasfeest kepada St. Nicholas dirayakan setiap tanggal 5 Desember dengan tradisi bertukar kado antara penduduk di Pasar Baru, perayaan ulang tahun Ratu Wilhemina pada 31 Agustus yang dimeriahkan dengan pertunjukkan music anak-anak dan kesenian lokal yang disebut Tanjidor, dan terdapat pula perayaan Cap Go Meh pada hari kelima belas tahun baru chinese sebagai perayaan yang paling menarik di antara semua festival.

Perayaan Peh Cun biasanya dirayakan pada hari kelima bulan kelima pada kalender Chinese. Selama acara berlangsung, terdapat perlombaan perahu naga di Kali Ciliwung. Pada masa kkini, perayaan tahun baru chinese dan Cap Go Meh masih dirayakan secara tahunan disana. Pemerintah DKI Jakarta juga menambahkan acara Festival Pasar Baru yang dirayakan setiap tanggal 22 Juni sebagai peringatan ulang tahun Jakarta. Biasanya dirayakan dengan pameran, parade, pertunjukkan music, festival kuliner, kompetisi mendayung perahu, dan diskon besarbesaran pada pertokoan di sepanjang Jl Pasar Baru.

Potensi kreatifitas Pasar Baru merupakan hasil dari diversifikasi etnis yang tinggal di Jl. Pasar Baru dan sekitarnya. Terlihat dari keberagaman makanan atau budaya kuliner yang berkembang, seperti, kuliner chinese dan india, dengan penyesuaian rasa lokal. Bakmi Aboen dan Bakmi Kelinci merupakan restoran terkenal chinese-indonesian yang berkembang disini, juga terdapat restoran india di Jl. Pintu Air. Restoran Tropic juga merupakan restoran tertua yang didirikan sejak tahun 1950 dan menyediakan berbagai makanan chinese-european-indonesian. Diversifikasi makanan jalanan juga memperkuat Pasar Baru sebagai salah satu pusat makanan di Jakarta. Makanan jalanan lokal seperti Kue Pancong, Kerak Telor, Kue Ape, dan Martabak merupakan contoh makanan campuran asal india dengan rasa lokal. Memang, kuliner Pasar Baru merupakan salah satu produk pencampuran budaya yang menunjukkan potensi kreatifitas yang jelas dalam meningkatkan perekonomian dan sebagai bentuk identitas Pasar Baru.

Pada analisis kegiatan pengguna di kawasan Pasar Baru seperti masyarakat, pelajar, pedagang, dan seniman. Pergerakan manusia dari first place ke second place melewati ruangruang antara berupa jalan gang. Namun, third place di Pasar Baru tidak memadai menyebabkan pengguna banyak menghabiskan waktu senggangnya di jalan gang untuk sekedar bersosialisasi. Dari analisis yang dilakukan Pasar Baru memiliki potensi untuk dikembangkan sebagai ruang kreatif, namun ruang ketiga yang hadir berupa ruang-ruang sisa di antara kepadatan bangunan (lihat gambar 5).
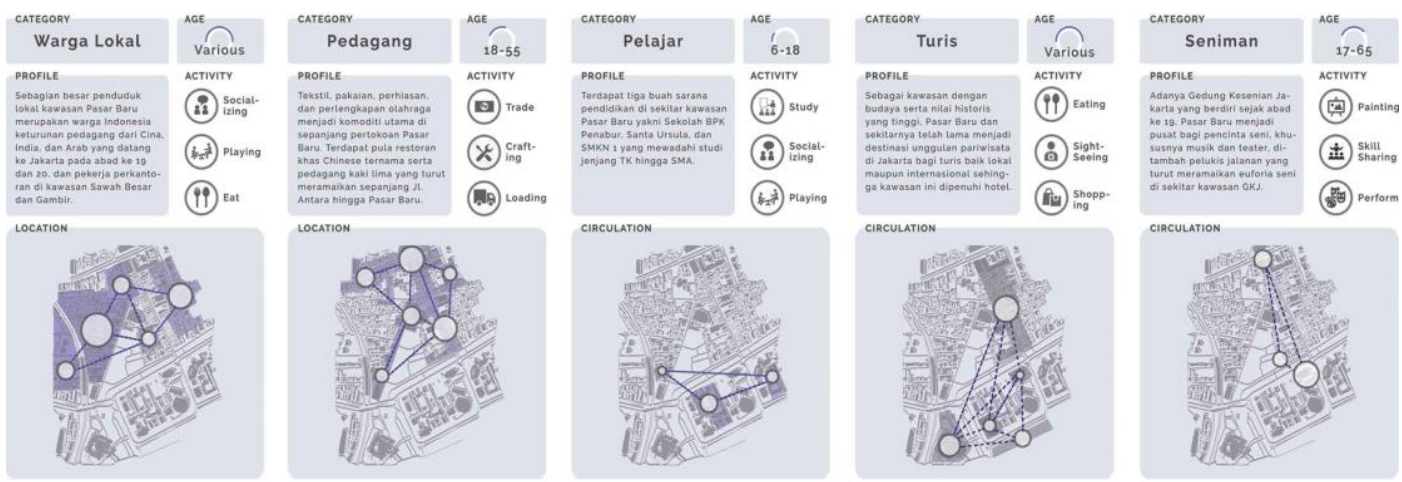

Gambar 5. Analisis Kegiatan Pengguna di Kawasan Pasar Baru Sumber: Penulis, 2020 
Program yang dipilih berupa fashion berperan sebagai wadah perdagangan tekstil dan aksesoris pakaian, sentra pedagang kaki lima berperan sebagai wadah bagi masyarakat Pasar Baru untuk bersosialisasi sambil menyantap makanan khas chinese dan india yang dikenal sejak dulu, dan workshop bagi pelukis jalanan yang banyak tersebar di kawasan Pasar Baru. Diversitas Pasar Baru yang tinggi menjadi salah satu indikator terpenting dalam pembentukan ruang kota yang kreatif, dikombinasikan dengan kondisi eksisting Pasar Baru sebagai pusat perekonomian maka muncul potensi mengembangkan kawasan tersebut sebagai sentra ekonomi kreatif (lihat gambar 6).

Konsep massa bangunan mengambil konsep rajutan yang merupakan proses penyatuan untaian benang-benang menjadi satu kesatuan dimana di dalam rajutan tersebut dimungkinkan adanya penggunaan pola dan warna yang beragam. Konsep rajutan identik dengan Pasar Baru yang merupakan kawasan multietnis dan multifungsi di dalamnya. Rajutan sendiri merupakan implementasi dari tekstil sebagai komoditas utama di kawasan Pasar Baru (lihat gambar 7 dan 8).

Pada proses pembentukan massa, dibentuk dua sumbu yang bersilangan sebagai implementasi dari pola gerakan tangan ketika merajut. Massa bangunan lalu dibagi menjadi beberapa bagian yang kemudian dihubungkan membentuk sebuah konektivitas dalam rajutan antar massa bangunan. Permainan ketinggian yang berbeda dibentuk untuk memberikan kemenerusan visual antar massa dan dengan bangunan sekitarnya. Jembatan eksisting di Kali Ciliwung didesain ulang untuk menghubungkan area Jl. Antara dengan Jl. Pos dan menghubungkan area J. Pos dengan lantai satu bangunan.

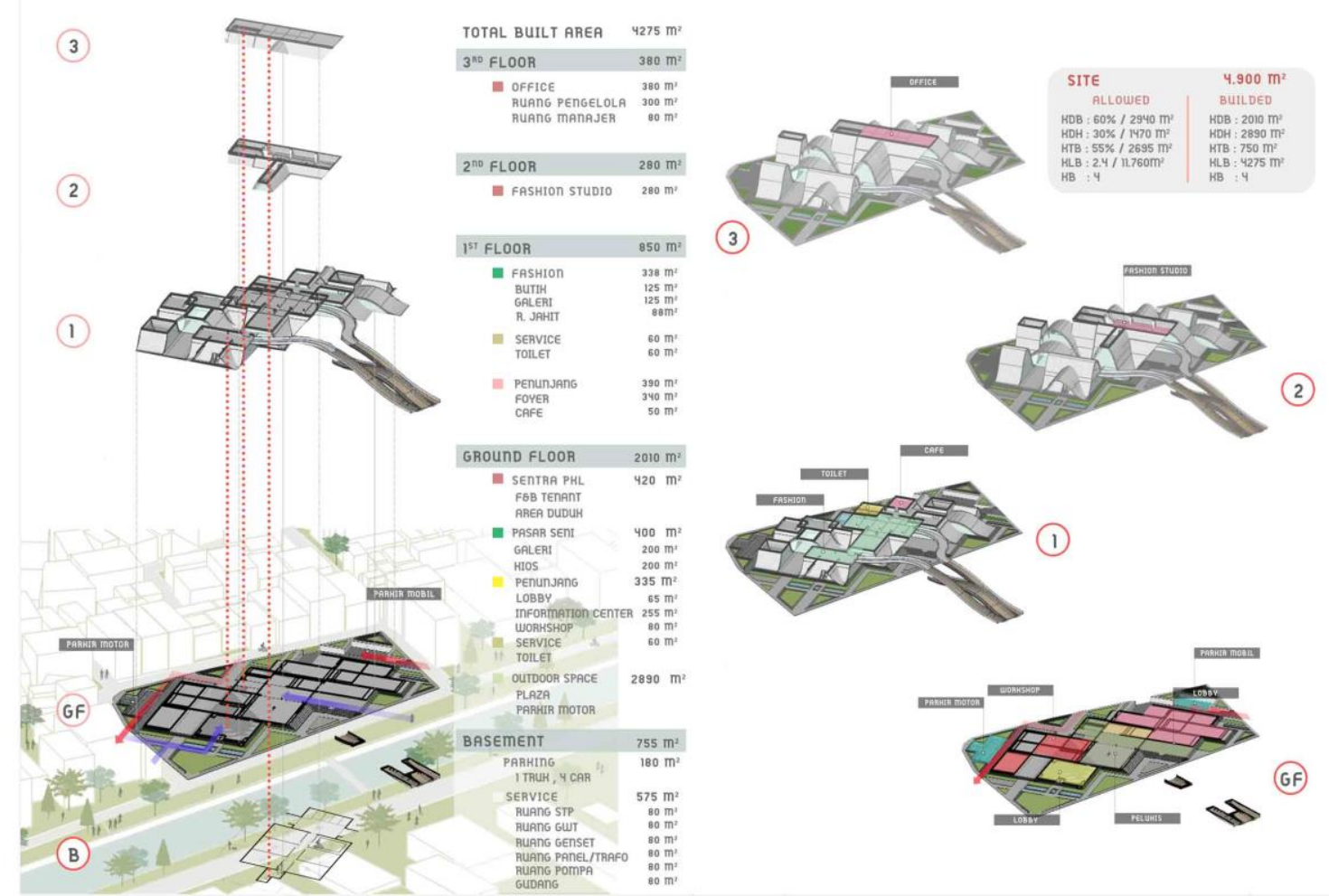

Gambar 6. Program Ruang Rajutan Keberagaman Masyarakat Pasar Baru Sumber: Penulis, 2020

Massa bangunan digambarkan seperti untaian benang yang kemudian dirajut menjadi sebuah kesatuan. Massa bangunan memiliki bentuk lengkung yang sempurna serta tidak membentuk pertemuan sudut. Stuktur cangkang dipilih sebagai jenis stuktur yang mencapai sintesis paling murni antara bentuk arsitektural dan stuktural. Penggunaan stuktur cangkang dipilih dikarenakan bentuk stukturnya yang dapat mempertahankan esensi dari konsep massa 
yang hendak dicapai. Fasad bangunan digunakan sebagai penutup massa bangunan untuk mempertahankan kemenerusan visual dari luar ke dalam bangunan dan dari arah sebaliknya (lihat gambar 8).

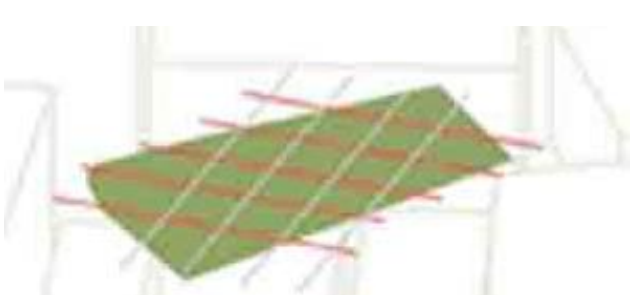

Dibentuk dua sumbu yang bersilangan sebagai implementasi dari pola gerakan tangan ketika merajut.

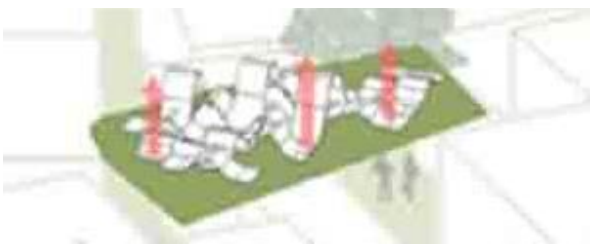

Permainan ketinggian yang berbeda dibentuk untuk memberikan kemenerusan visual antar massa dan dengan bangunan sekitarnya

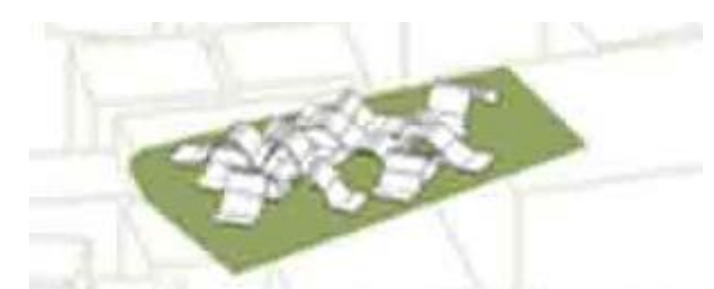

Massa bangunan lalu dibagi menjadi beberapa bagian yang kemudian dihubungkan membentuk sebuah konektivitas. rajutan antar massa bangunan

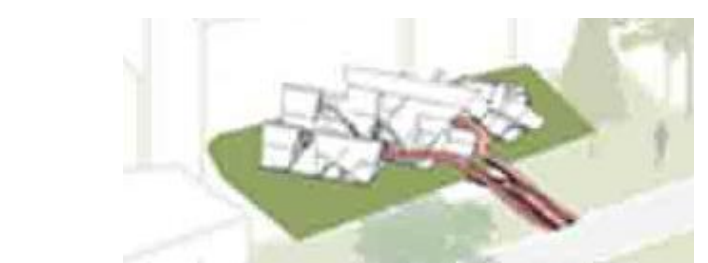

Jembatan eksisting di Kali Ciliwung didesain ulang untuk menghubungkan area $\mathrm{Jl}$. Antara dengan Jl. Pos dan menghubungkan area Jl. Pos dengan lantai satu bangunan

Gambar 7. Diagram Gubahan Massa Sumber: Penulis, 2020

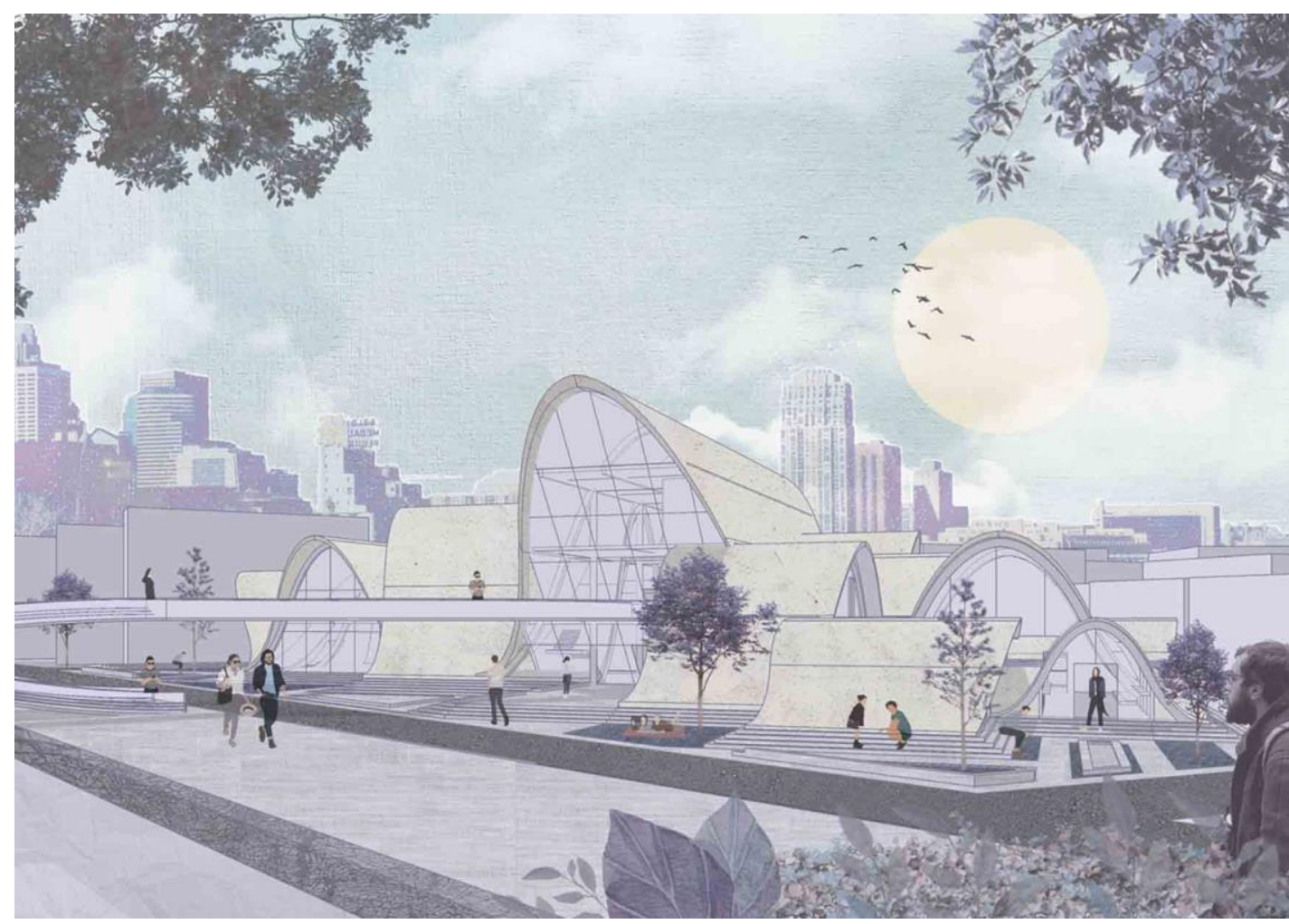

Gambar 8. Perspektif Eksterior Ruang Rajutan Keberagaman Masyarakat Pasar Baru Sumber: Penulis, 2020

\section{KESIMPULAN DAN SARAN}


Terdapat empat prinsip pembentukan Creative Place, third place sebagai ruang publik tidak hanya untuk bersosialisasi saja namun dapat mendatangkan masyarakat yang kreatif untuk saling bertukar ide membentuk Creative Class sebagai sumber daya ekonomi. Diversifikasi sebagai salah satu dari prinsip tersebut merupakan salah satu poin penting yang muncul secara dominan di Pasar Baru melalui keberagaman berbagai aspek budayanya seperti etnis, langgam arsitektur, kuliner, produk kesenian, dan lainnya. Aspek-aspek kebudayaan tersebut pun diangkat sebagai konsep dasar pemograman dalam bangunan Ruang Rajutan Keberagaman Masyarakat Pasar Baru.

Jl. Antara merupakan pusat aktifitas kawasan di Pasar Baru selain Jl. Pasar Baru itu sendiri dan Jl. Pintu Air Raya. Terletak berseberangan dengan JI. Pos dan jajaran bangunan historis di sepanjang sisinya. Namun dibatasi oleh Kali Ciliwung sehingga secara pencapaian menarik namun tidak didominasi oleh akses kendaraan sehingga nyaman dilalui pejalan kaki. Jl. Antara juga menghubungkan kawasan Pintu Air dan Pasar Baru sebagai sentra ekonomi dan diharapkan melalui keberadaan Ruang Rajutan Keberagaman Masyarakat Pasar Baru dapat menambah diversifikasi fungsi sekaligus mempromosikan citra budaya di Pasar Baru sebagai penunjang sektor ekonomi kreatif masyarakat.

Diversitas menjadi konsep dasar dalam penerapan bentuk massa bangunan. Massa mengambil konsep rajutan yang identik dengan kawasan Pasar Baru sebagai kawasan multietnis dan multikultural. Rajutan sendiri diimplementasikan melalui bentuk massa yang dibentuk atas beberapa untaian massa yang lalu dibentuk konektivitas antar massa. Program yang diangkat didasarkan pada analisis kegiatan pengguna di kawasan Pasar Baru seperti fashion, sentra pedagang kaki lima, dan workshop pelukis.

\section{REFERENSI}

Florida, R. (2002). The Rise of Creative Class. New York: Basic Books. Jacobs, J. (1961). The Death and Life of Great American Cities. USA: Vintage Books. Levebre, H. (1992). The Production of Space. Oxford: John Wiley and Sons Ltd. Oldenburg, R. (1999). The Great Good Place. USA: Da Capo Press. Schulz, C. N. (1979). Genius Loci. New York: Rizzoli. Smith, A. (1776). Wealth of Nations. William Stratan: Scotlandia. Winata, S. (2019). Open Architecture as Third place. 
